\title{
Demographic and health attributes of the Nahua, initial contact population of the Peruvian Amazon
}

\author{
Características demográficas y de salud de la población Nahua: \\ población en contacto inicial de la Amazonía Peruana
}

Dante R. Culqui ${ }^{1}$

Ana Ayuso-Alvarez ${ }^{1}$

Cesar V. Munayco ${ }^{2}$

Carlos Quispe-Huaman ${ }^{3}$

Percy Mayta-Tristán ${ }^{4}$

Juan de Mata Donado Campos ${ }^{5}$

${ }^{1}$ Epidemiology Field Program, Centro Nacional de Epidemiología, Instituto de Salud Carlos III. Sinesio Delgado 4, Chamartín. 28029 Madrid España. danteroger@hotmail.com ${ }^{2}$ Department of Preventive Medicine and Biometrics Uniformed Services, University of Health Sciences.

${ }^{3}$ Instituto Nacional de Desarrollo de Pueblos Andinos, Amazónicos y Afroperuanos.

${ }^{4}$ School of Medicine, Universidad Peruana de Ciencias Aplicadas. ${ }^{5}$ Department of Preventive Medicine and Public Health, School of Medicine, Universidad Autónoma de Madrid.
Abstract We present the case of the Nahua population of Santa Rosa de Serjali, Peruvian Amazon's population, considered of initial contact. This population consists of human groups that for a long time decided to live in isolation, but lately have begun living a more sedentary lifestyle and in contact with Western populations. There are two fully identified initial contact groups in Peru: the Nahua and the Nanti. The health statistics of the Nahua are scarce. This study offers an interpretation of demographic and epidemiological indicators of the Nahua people, trying to identify if a certain degree of health vulnerability exists. We performed a cross sectional study, and after analyzing their health indicators, as well as the supplemental qualitative analysis of the population, brought us to conclude that in 2006, the Nahua, remained in a state of health vulnerability.

Key words Health vulnerability, Indigenous People, Demography, Amazon, Public health, Peru
Resumen Presentamos el caso de la población Nahua de Santa Rosa de Serjali, una población de la región Amazonica del Perú, considerada en contacto inicial. Esta población está compuesta por grupos humanos que durante mucho tiempo han decidido vivir en aislamiento, pero últimamente han comenzado a vivir un estilo de vida más sedentario y en contacto con la población occidental. Hay dos grupos de contacto iniciales plenamente identificados en el Perú: Los Nahuas y los Nantis . Las estadísticas de salud de los nahuas son escasas. Este estudio ofrece una interpretación de los indicadores demográficos y epidemiológicos del pueblo Nahua, tratando de identificar si existe un cierto grado de vulnerabilidad de la salud. Se realizó un estudio transversal, y después de analizar sus indicadores de salud, así como el análisis cualitativo complementario de la población, nos llevó a la conclusión de que en el año 2006, los nahuas, aún presentaban un estado de vulnerabilidad en salud.

Palabra clave Vulnerabilidad, Poblaciones indígenas, Demografía, Amazonía, Salúd pública, Perú [retirar una palabra clave] 


\section{Introduction}

It is considered indigenous population the original inhabitants of an area, or to those who are descendants of the original inhabitants who were colonized, and those who live in indigenous areas and are accepted by the indigenous community ${ }^{1}$. Although there are many controversies on the use of the term indigenous ${ }^{2}$, and even the United Nations have not agreed on a universal definition $^{3}$, it is recognized that the indigenous population, both globally and regionally, have been largely neglected ${ }^{4,5}$.

According to United Nations estimates, there are about 370 million indigenous people worldwide distributed in over 90 countries and with more than 500 different languages; around 50 million of them living in Latin America ${ }^{3}$. Unlike countries such as Canada, Australia, and New Zealand, indigenous health information is relatively scarce in the Americas ${ }^{3}$. Official census figures from Peru indicate that, in 2007, there were 1786 indigenous communities in 11 of its 24 departments ${ }^{6}$, belonging to 76 ethnic groups (60 of them located in the Amazon) and with 68 different languages ${ }^{7}$. Peru also recognizes two special groups of indigenous people, based on their social relations with the rest of the national population and its social vulnerability as a consequence of such relationship: populations in voluntary isolation and initial contact populations.

Several groups in initial contact exist in Peru; one of the most studied has been the Nanti group $^{8}$. Another one, with fewer studies about its vulnerable status in health, is the Nahua group. Populations in initial contact stage (i.e., Nahua, Nanti), form a bridge between native groups in isolation — small and isolated groups moving throughout the jungle of the departments of Cusco, Ucayali, and Madre de Dios- and the contacted native population.

Our research's objective was to describe the demographic and health attributes from the Nahua population and to ascertain whether this population is still in a state of health vulnerability.

\section{Materials and method}

\section{Definitions}

Health vulnerability. From a historical perspective, the term vulnerability reflects the fact that thousands of indigenous cultures no longer exist or have been marginalized to become extinct, following contact with westernized cultures ${ }^{9}$. For our study, however, we adopted a social perspective, by which health vulnerability refers to those social inequalities, such as different living conditions, skills or abilities to manage risk, access to resources and social networks, access to health services, which have a direct impact in the health of the population, this include those categories that act as cause of health among different population groups ${ }^{10}$.

Several studies have found some segments of society more vulnerable to disease and death than others, such as the young, the elderly, women, ethnic minorities, people with little social support, little or no access to education and health, low income and the unemployed ${ }^{11}$.

In this study, we operationally consider that a population has some type of health vulnerability when it shows noticeable deficiencies in the provision of quality health services, or when it has wide health gaps. We documented and described this vulnerability with rate indicators of natality, mortality, and morbidity, contrasting them with those of a Western society as well as with other contacted native populations and populations in initial contact.

Populations in isolation. An indigenous group, or part thereof, which has not developed sustained social relationships with other members of the national society, or having done so, has chosen to discontinue that practice ${ }^{12}$. They are an indigenous sector that due to previous traumatic experiences, has voluntarily chosen to, or was forced to, isolate themselves from the rest of the national society and sometimes from other indigenous communities in exchange for their survival, even in unfavorable conditions $s^{13,14}$.

Peoples in initial contact. Are those that occasionally form relationships with other groups of people, have had or have a sporadic or continuous link with other foreign cultures, whether indigenous or not, and their situation presupposes vulnerability due to how traumatic or destabilizing the contact would had been ${ }^{13}$. This group includes indigenous people in recent contact, that despite their interaction with the rest of society, predominantly maintain their traditional organizational patterns and subsistence, poor exchange of products and they are still very vulnerable to suffer epidemics by their interaction with external agents ${ }^{8}$.

\section{Characteristics of the studied population}

For the protection of groups in voluntary isolation and initial contact in Peru, this country 
has created land reserves. Currently, there are 6 recognized reserves for indigenous people in isolation ${ }^{15}$. One of these reserves is the one established in favor of the Nahua, Kugapakori Nanti (RTNKN) and other ethnic groups, located between the departments of Cusco and Ucayali. The areas inhabited by these groups are known for being among the richest in natural resources, both in flora and fauna, as well as oil and gas $^{16}$. In this region there are two identified initial contact groups: the Nahua and the Nanti.

Initially, the Nahua lived in isolation, devoted to hunting, fishing, and wood gathering, individually or in small tribes. Currently, they live in the town of Santa Rosa de Serjali (Figure 1, top pictures). In addition to subsistence activities, they occasionally engage in logging, sometimes exploited by illegal loggers and sometimes by their own initiative, with the intention of getting some kind of economic benefit for subsistence ${ }^{17}$.

\section{Type of study}

Qualitative and quantitative descriptive study.

\section{Population and sample}

We did not use a sample; we studied the total Nahua population at 2006. Total population data from 1987 to 2005 were obtained from the

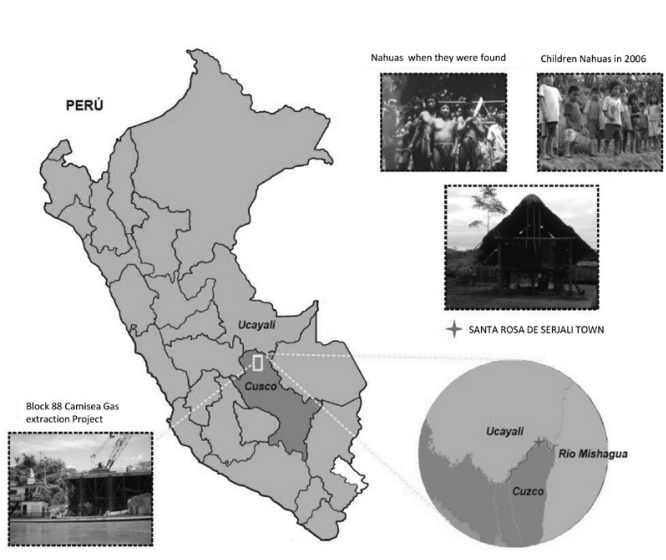

Figure 1. Geographic location and characteristics of the Nahuas.

Source: Nahua photography from when they were found Dominican order's Sepahua Peru files/other pictures source: Dante Culqui. log books of the Dominican mission; in addition, population data by sex and age were obtained from the 2006 local population census carried out by the Dominican nuns $(\mathrm{n}=314)$. Data on births, for the 1987-2006 period, were collected from the log books of the Dominican volunteers. Data on morbidity for 2006 were collected from the log book of health care of the Dominican volunteers as well as from Sepahua's health center registry (the district capital town, located eight hours away by boat) which conducts periodic health care visits in Santa Rosa de Serjali. Mortality data, from the 1995-2005 period, were collected from the Dominican volunteer's records, and contrasted with the information from Santa Rosa de Serjali's cemetery.

Dominican volunteers, acting in their humanitarian mission in the Santa Rosa de Serjalí region, did not gather information through standardized data collection forms or tools. Instead, they used a 'health notebook', in which the patient's name, demographics (age, sex, offspring size), and main diagnosis were recorded, by hand. We transcribed the above mentioned data into an Excel file. The information was mostly kept at the health center, as well as at the Dominican mission premises.

\section{Population pyramid and rates}

The population pyramid for 2006 was created using that year's census information. In addition, following the definitions of rates established by the WHO, we estimated the general mortality rate (GMR), the infant mortality rate (IMR), and the birth rate (BR), disaggregated by sex and age group whenever appropriate. GMR corresponded to the total number of deaths in a specified period divided by the total population (and expressed per 1,000 inhabitants); IMR was the number of deaths among children aged 0 to 1 over the calendar year, divided by the number of live births in the same year (expressed per 1,000); BR was computed as the number of births divided by the total population in a specified year (expressed per 1,000).

Quantitative analysis we performed using SPSS 18.0; Microsoft ${ }^{\circledR}$ Excel was used to produce graphics; maps were created with gvSIG.

\section{Qualitative Analysis}

With the objective of shed some light on the social causes of population health in the Nahua, contextualize their situation, and interpret the 
results of the quantitative analysis, we used engaged observation and informal or semi-structured interviews to key community informants as qualitative research techniques.

Fieldwork and participant observation was conducted from January 2004 to the last months of 2005. During this period, trips were made to the town of Santa Rosa de Serjali on a bimonthly basis and with duration of approximately two weeks each time. The research team consisted of a physician-epidemiologist, a geological engineer, a geographer engineer, an anthropologist, and a lawyer. Each of its members had specific objectives listed in the RTNKN Protection Plan, determined by the National Indigenous Amazonian and Afro-Peruvian Institute (INDEPA), with funding from the Inter-American Development Bank.

The RTKNN protection plan was aimed at guaranteeing, the respect of the RTKNN groups rights and territories. In the area of health care, it tried to ensure an adequate health offer, in harmony with the social and cultural characteristics of the reserve. To preserve anonymity, the names of key informants are not disclosed. Instead, the terms key informant land key informant 2 are used in each citation.

\section{Ethical Aspects}

The study was reviewed and approved by the research committee for the Kugapakori Nahua Nanti reserve protection area, belonging to INDEPA, but did not go through the Ethics Committee, because at that time and place, the ethics committee were not yet available; on the other hand, anonymity was preserved. Informed consent was obtained from interviewees in advance; information was processed anonymously.

\section{Results}

\section{Demography}

According to the 2006 census, Santa Rosa de Serjali had a population of 314 people; 174 (56\%) male, and 140 (44\%) female. All were grouped into 63 families.

We observed fewer people, especially women, in the 20-24 years age group, in comparison to other age groups. Also, there was a smaller number of people on the 0-4 years group in comparison to the group of 5-9 years (Figure 2).

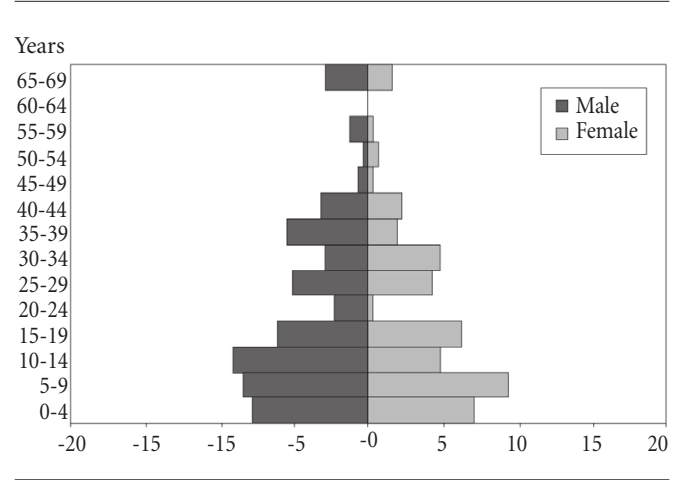

Figure 2. Nahua Population pyramids of Santa Rosa de Serjali-Peru, 2006.

\section{Mortality}

There were 22 deaths recorded in the Nahua population in the 1995-2005 period. The general mortality rate varied between 3.2 and 6.4 per 1000 inhabitants per year. Infant mortality rates were very high, reaching a peak of 200 per 1000 inhabitants in the year 2001(Figure 3).

\section{Causes of death}

The main causes of death in adults in the period studied were: unknown cause (43\%, 3 deaths) followed by acute diarrheal disease (ADD) (29\%, 2 deaths), drowning (14\%, 1 death), and intestinal obstruction (14\%, 1 death).

The main causes of infant mortality until 2005 were: unknown cause $(40 \%, 6)$, pneumonia $(33 \%, 5)$ and stillbirth $(7 \%, 1)$, starvation $(7 \%$, $1)$, congenital problems $(7 \%, 1)$, and tetanus $(6 \%, 1)$.

The low level of precision in the diagnosis is probably because no medical staff conducted most of them during these years, limiting the ability to identify some diseases.

Qualitative analyses identified some social and cultural practices of the Nahua group that could influence mortality, and they should be explored in more depth. Key informant 1 interview suggested that in special occasions euthanasia rites might have taken place, especially for people suffering a serious illness.

... The patient was very ill, and then the elder gathered, they went to see him, and gave him something to drink. I do not know what it was. The next day the patient died, and the whole town was quiet ... (Key Informant 1). 
Figure 3. Overall mortality rate (TMG) and infant mortality rate (IMR) per 1000 inhabitants in the Nahua population of Santa Rosa de Serjali 1995-2005 Peru*.

"In the TMI, 14 deaths were studied during the study period. The number of dead children was never greater than 4 in each year. In the $T M G, 22$ deaths were studied during the study period. The number of deaths was not greater than 7 per year. However, a calculation of rates per 1000 inhabitants was performed in order to allow comparison with other rates in the world.

Further more the Nahua population continue to practice some migration processes that have been passed from generation to generation, related to subsistence activities, such as food gathering. These activities might add in some mortality and morbidity risks, as key informant 2 interview seems to indicate. For example, during the migration to get Taricaya eggs (turtle eggs) encounters with people in isolation occur. Sometimes the contact even occurs with groups that have not been adequately documented and injuries and in some cases casualties were not properly recorded:

We went to the headers and they they started to bite [shoot with arrows] and we had to shoot, some propably have died, we have arrows that are different from ours. (Key informant 2)

These circumstances may also contribute to increase their vulnerability. There are some cultural practices that although they could make room for suspicion, they could easily influence the infant mortality rate. Similar customs have been reported in other native populations. Our key informant 1 , said that in at least a couple of occasions, he has witnessed cases when newborn babies dissapear:

... We were following up on a pregnant woman, a young woman who had no husband, that looks really bad, when delivery was getting closer, the girl said she was not pregnant ... it was not the first time it happens in women who have no husbands ... (key Informant 1)

NatalityThere were 184 births in the Nahua population between 1987 and 2006. The birth rate was quite high in all years studied; however, slight decreases were observed between 2001 and 2003 (Figure 4).

\section{Birth rate by department}

Birth rates in the Nahua population (i.e., Serjali)were almost two times higher than Peru's in the two quinquennia periods prior to 2006 (Figure 5).

There are some social factors, such as polygamy, that might influence birth rates. This behavior has been observed in Alto Amazonas groups in northern Peru in groups such as the Shipibo ${ }^{18}$ which also showed a high birth rate. However, in the case of the Nahua, polygamy has been limited to the community leader (Curaca).

\section{Morbidity}

In 2006, 114 Nahua people were treated for health issues. The 10 leading causes of disease observed werebronchitis (26 persons; $22.8 \%$ ); lowback pain $(13.2 \%)$, acute pharyngitis $(11,4 \%)$; arthralgia / arthritis $(8.8 \%)$; gastritis $(8.8 \%)$; complex phar- 


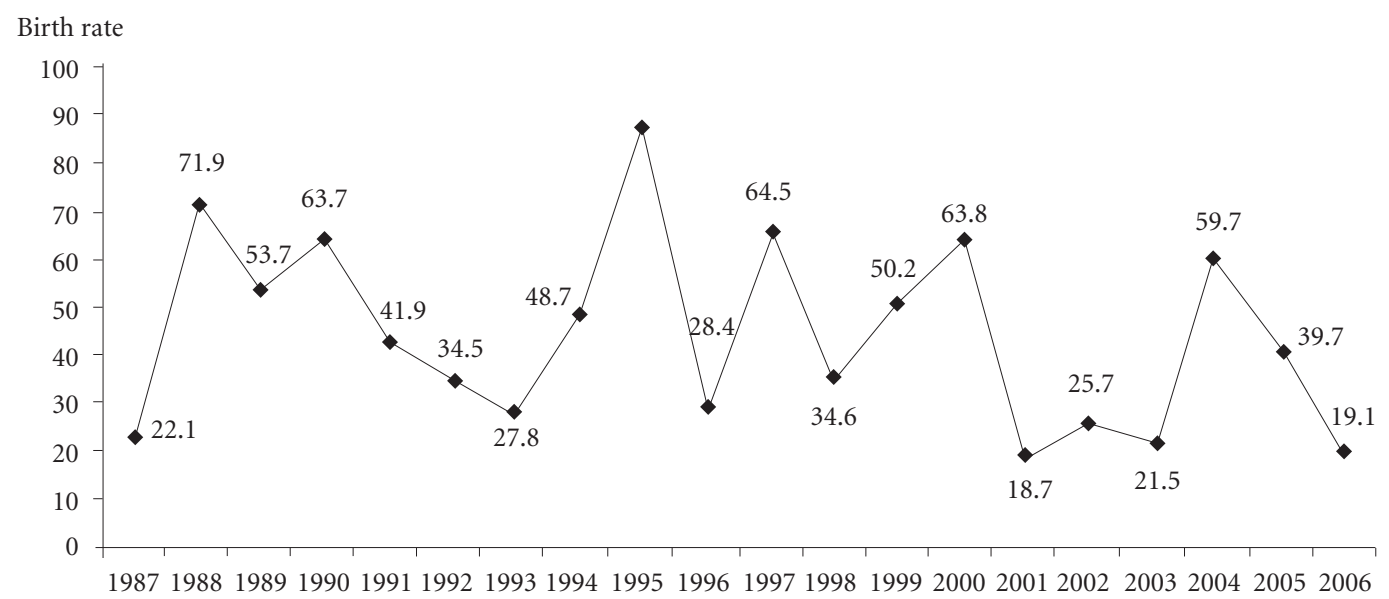

Figure 4. Birth rate per 1000 inhabitants. Nahua population of Santa Rosa de Serjali. Peru 1987-2006*.

* We studied 184 infants in the study period, the number of live births ranged from 5-17 children per year. However, a calculation of rates per 1000 inhabitants was performed in order to allow comparison with other rates in the world.

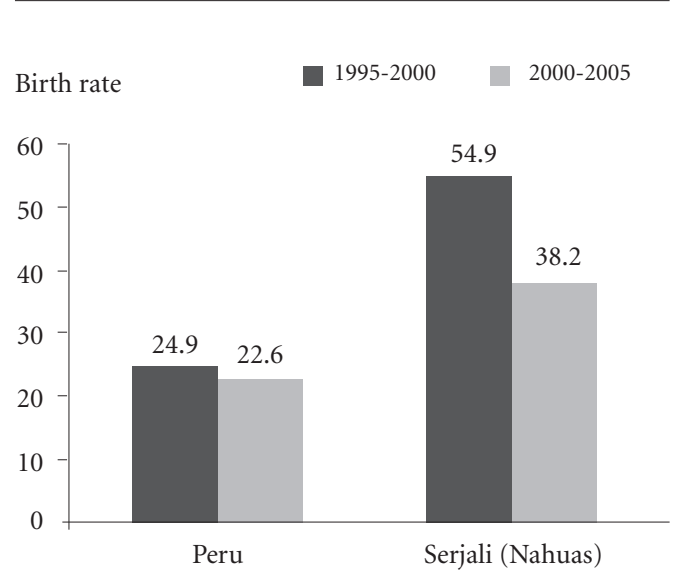

Figure 5. Birth rate per 1000 inhabitants. Comparison between: Peru's and Nahua population 1995-2000 and 2000-2005*.

"We studied 184 infants in the study period. The number of live births ranged from 5-17 children per year; however, a calculation of rates per 1000 inhabitants was performed in order to allow comparison with other rates in the world.

yngitis $(5.3 \%)$; poliartralgia (5.3\%); conjunctivitis $(4.4 \%)$; anemia $(3.5 \%)$, and pyoderma $(3.5 \%)$.

\section{Discussion}

The results presented in this analysis suggest that in 2006, the Nahua group was in a situation of health vulnerability, presenting high rates of general and infant mortality, and poor recovery in population growth.

\section{Social integration}

It is likely that the Nahuas' initial migration occurred during the period of isolation, before the 40 s due to the rubber boom. Later in the $70 \mathrm{~s}$ and 80 s it was due to the presence of oil exploration companies.

In the 80s, during seismic prospecting activities for hydrocarbon exploration, the "trocheros nativos" (people who identify and open new paths in the jungle) contacted the first Nahuas. Following this first contact they were relocated to the city of Sepahua. There is controversy surrounding this relocation, because according to some informants it was forced and according to others it was consensual. After spending some time in Sepahua, some difficulties in the interaction with the population arised. This is when the Dominican missionaries helped the Nahuas move to a nearby region. A village called Santa Rosa de Serjali was created. Currently, there is gas exploitation getting closer to the area of the Nan- 
ti population than the Nahua population, who are located in the area bordering the reserve. The integration process continues today, with a slow but gradual progress that could be analyzed in terms of the proposed indicators.

On the other hand, the contact of this population with Western culture changes the environment of the native populations, changes their live conditions and their worldview. All of it affects their health. Thus it is likely that to the existing diseases among pre-contact Nahuas (of which we have limited records), new diseases that appear as a result of their interaction with other societies will be added, diseases like influenza ${ }^{19}$, tuberculo$\operatorname{sis}^{20}, \mathrm{HIV}^{21}$ and hepatitis $\mathrm{B}^{22}$. Finally, contact with Western culture makes them particularly vulnerable, with difficulty to resist and adapt to threats that loom over their health.

\section{Population Pyramid}

It is likely that at the begining, the population pyramids of the Nahua showed age group bands without population, which demonstrates that the settling process didn't follow the same rhythm for all age groups. As years passed and among other reasons like religious activists stimulus or in some cases by a decision of the natives themselves, such population's age groups, began to populate with other Nahua of different ages. These Nahuas used to live wandering, but then decided to join the Nahua sedentary population, located in Santa Rosa de Serjali. Unfortunately, we do not have censuses previous to 2006 that clearly would depict this process. Actually, few native populations have reliable census or vital statistics, for that reason than many indigenous societies know little about their own demographic processes ${ }^{23}$.

Even over the years, the age groups have increased in number. The year 2006 saw a decrease in the base of the pyramid population ( 0 - 4 years group) in relation with the 5-9 years group, because as we have seen, this group has a high birth rate. This could explain the state of vulnerability of this population during those years. This same pattern has also been observed in the Nanti group, which in 1998 and 2002, presumably by the presence of epidemics such as malaria and acute diarrhea disease, had a decrease especially in the group of children under 5 years. However, not only epidemics can cause this type of shortening at the base of the population pyramid, but also the difficulties to access health services ${ }^{6}$, as Nahua are 8 hours away by boat to the nearest health center. Even though by 2006 they had a radio to communicate in case of emergency, in previous years there experienced serious communication difficulties. The Nahua, from a social standpoint, have experienced a much greater integration with Western society than the Nantis (Initial contact group from the same area). However, in the year 2006 we also saw an important shortening of the base of the Nahua population pyramid (group of 0-4 years). The demographic characteristics of the Nahua were similar to those of other Amazon indigenous populations with high percentage of children under 15 years, high fertility and children mortality ${ }^{24-26}$.

The indigenous population census carried out in Peru don't include recently encountered populations like the Nahua ${ }^{6}$. Because census are instruments for public policy planning, leaving these populations out of them makes them vulnerable ${ }^{27}$, as they are in practice, invisible for the government.

\section{Mortality}

The Nahua GMR is variable and high in all the years studied. This is consistent with literature that said the GMR is always higher in indigenous populations than in non-indigenous populations ${ }^{3}$.

Furthermore, it was observed that up until 2004 , the IMR was greater than 100 , then it started to decrease. However, the levels are still high compared to indigenous populations of developed countries like Canada, Australia or New Zealand ${ }^{3,28}$, where there has been a further decline in infant mortality. Although, it is clear that the indigenous population of South America is quite different compared to the population in comparation $^{29}$. In the Nahua, we observed than there was a decline in IMR in the last years of this study. Nevertheless, the IMR of 2004 and 2005 remain high, comparable in the year 2005 with countries such as Cameroon, Equatorial Guinea, and Ethiopia among others. However, the IMR for Peru was estimated at 25 per 1000 inhabitants the same year, according to reports from the World Health Organization ${ }^{30}$. On the other hand, some studies have shown that the IMR in Peru's indigenous population can be 3 or 4 times the national average $e^{31,32}$. Also, Ecuador shows that infant mortality rates in indigenous people have become greater than 100 per 1000 inhabitants ${ }^{33}$. Other authors reported that the mortality rate among rural indigenous children is 70\% higher than for non-indigenous children ${ }^{34}$. 
The main cause of mortality among adults is unknown, probably due to difficulties in the recording and diagnosis of death, not having permanent medical staff, (at least until 2006). In second and third place are acute diarrhea and drowning as main causes of death. This is important, because the only access to the area is through the river, sailing about 8 hours from Sepahua, (the nearest town in Ucayali) and the native are fairly used to this kind isolation. This situation has also been reported since 1968 when Shipibo population described it as death from motor vehicle accidents ${ }^{35}$. This also increases their risk of vulnerability as there are areas where you can only use peque peque, (a narrow and low raft where one seats behind the other) which can easily cause accidents. Recently publication about isolated population in Brazil referred when Nahua population newly contacted, $60 \%$ died between 1983 and 1985 from influenza ${ }^{36}$.

Among the causes of infant mortality that have been observed, the main causes seem to be pneumonia and stillbirths. In this regard, some authors mention infanticide in other tribes of the Amazon. This was evidenced in the Yanomami in Brazil with rates of 15 to $20 \%{ }^{37}$, and the Saranahuas in $\mathrm{Peru}^{38}$, who maintained the tradition of having children every three years and practiced infanticide to make births occur only on those years. In this regard, during an interview to a key informant, he mentioned the disappearance of some babies, especially of mothers who did not have a known partner. However, the evidence in the Nahua population is scarce and inconclusive.

\section{Birthrate}

We did not observe a recovery of the birth rate, because its development is variable. Comparing the pyramid of the Nahua (2006) with the $\mathrm{Nanti}^{8}$, and the birth rate trend, there is not enough evidence to claim meaningful population growth. This is different to what happens in Brazil, where research has shown a demographic recovery in some indigenous groups ${ }^{39}$. However, when talking about indigenous "pre-contacted" in Mato Grosso (Brazil $)^{40}$, it is mentioned that this population experienced a dramatic population decline from 1910-1965. It was not until 1970 that they would experience a recovery (defined as a new increase in the birth rate), so perhaps a sustained recovery of the birth rate in the Nahua population could be very slow. Further, in the 5 years prior to 2006, the decline in the birth rate in the Nahua population has been greater than the one of the neighboring departments of Cusco and Ucayali, and much higher than the decline in the birth rate of Peru.

\section{Morbidity}

Until 2006, the staff of Sepahua's health center visited them to provide care, every three to four months each year. It is that during this patient visits in 2006 the identified bronchitis as the main cause of illness, followed by back pain. Back pain is a pathology that is closely related to their regular activities, such as long walks with heavy loads of timber, which could turn into an arthralagia or polyarthralgia, typical of the manual activities they perform, including fishing, hunting and others. We did not observe other infectious diseases very common in this area (Malaria, Leishmania, etc.) probably due to the lack of technical personnel in the diagnosis of other diseases and limited resources for diagnostics ${ }^{41}$.

\section{Limitations of the study}

The information is current up to the year 2006, because geographical access difficulties are complex and access to the area is only via the river or air. On the other hand, the collection of information had to be done manually for each entry as there was no electricity in the area. All these contributed to the delay in the process of collecting and analyzing information. The calculation of rates in such small populations, may mean a greater variability that in this context should be evaluated. Comparisons with other native populations should be made with caution, because there are few reports of populations in initial contact, as these ethnic groups constitute a special group within the native population. Up until 2006, causes of death were not properly registered, generating a high number of cases without a proper diagnostic, so further studies should be proposed.

In particular, we acknowledge the lack of properly furnished clinical records as a significant research drawback. The available records reflected only socio-demographic and current health status data of the interviewees: they did not capture their individual or familiar background, particular habits related to their bio-psychosocial health, nor their prognosis, treatment, or recovery. This lack of information limits the ability to explore the natural history of diseases and, more broadly, to know the trends and evolution of the health status of the Nahua people. 
The present study has some limitations from the qualitative standpoint, such as lack of triangulation. It would require further study of some of the practices gathered and mentioned above, including the practice of euthanasia.

\section{Conclusions}

In the analysis of health indicators, it was found that the Nahua has high infant mortality rates, high generally death rates and high birth rates. Additionally, the analysis of the population pyramid, the causes of morbidity and mortality, as well as the complementary qualitative analysis of this population, lead us to the conclusion that the Nahua, until 2006 was still in a process of health vulnerability. All this understood in accordance with our operational definition of a population that has deficiencies in health, or has a high probability and/or will have deficiencies in health care. It is likely that the indicators analyzed until 2006 have not changed significantly in the intervening years, as has happened in other native populations.

Currently, the Nahua are in permanent contact with society, and are improving their health and living conditions. They have to access to drinking water, get occasional visits from health workers, have a school, and some have even participated in the election of political authorities. It should be noted that the Peruvian state has a plan to protect native populations in isolation and specifically, the populations included in the
RTNKN. However, the institutions currently representing indigenous people continue to seek support for their development and begin to claim their rights from the Peruvian Government. They are probably aware that the social situation that affects their environment can also affect their health ${ }^{42,43}$.

The poor knowledge of populations in initial contact, makes necessary the dissemination of these results as a base line to understand the health situation of this population. It is important to mention that using census information alone, not health-related, is insufficient for that reason $^{44}$, the information presented is not only useful from the health point of view, but also helps understand the social context that may influence a health approach taylored to these populations. This information is not only valuable for the Peruvian state, but also for those Amazonic countries with large forests in South and Central America, that still preserve these native groups. Considering that population changes do not happen in few years, and despite the time elapsed between the completion of the study and the presentation of this results, we consider still valid, the findings presented in this document.

A deeper and broader qualitative study on the process of change the Nahua population is subject to (transition from a nomadic towards a sedentary lifestyle and contact with other communities), as well as the social, economic and cultural factors affecting the health-disease process in this population, would be very relevant to complement the analysis of vulnerability in health. 


\section{Collaborations}

All authors are responsible for the study design. DR Culqui, A Ayuso-Alvarez, C Quispe-Huaman, CV Munayco, P Mayta-Tristán, participated in the collection and analysis of information, as well as drafting the manuscript. Additionally DR Culqui and C Quispe-Huaman participated in the field work with communities, A Ayuso-Alvarez additionally participated in drafting the social and anthropological analysis, CV Munayco, P Mayta-Tristán and JMD Campos directed and oversaw all stages of the study. All authors interpreted the results, participated in the review of the first draft and the multiple versions of the item and are responsible for the final version of the manuscript.

\section{Acknowledgement}

To Houri Tamizifar and Augusto Abel Cangahuala Garcia, for their contribution to the development of this research. To the Dominican order, for their continued presence in the area of study. To the Dominican volunteers of Santa Rosa de Serjali, especially to Sister Mercedes Ravelo, for their valuable contribution and because they have provided the necessary information to reach the conclusion presented in this study. To Dr. Omar Trujillo Villarrroel of the Centro Nacional de Salud Intercultural of the Peruvian National Institute of Health, and Mr. José Dispipidigua; community Curaca, from whom we learned a lot. To Dr. Oscar Mujica from the Pan American Health Organization for their revision and comments to manuscript. Finally, to the whole Nahua population of Santa Rosa de Serjali, we hope that this document can help to demonstrate their real health status until 2006, and lessen in some way, the multiple postponements they have endured for many years. 


\section{Referências}

1. Montenegro RA, Stephens C. Indigenous health in Latin America and the Caribbean. Lancet 2006; 367(9525):1859-1869.

2. Kuper A. Indigenous people: an unhealthy category. Lancet 2005; 366(9490):983.

3. United Nations (UN). State of the world's indigenous people. New York: UN; 2009.

4. Stephens C, Porter J, Nettleton C, Willis R. Disappearing, displaced, and undervalued: a call to action for Indigenous health worldwide. Lancet 2006; 367(9527):2019-2028.

5. Pan American Health Organization. Health of indigenous peoples. Rev Panam Salud Publica 1997; 2(5):357362.

6. Instituto Nacional de Estadística e Informática. II Censo de Comunidades Indígenas de la Amazonía Peruana 2007. Lima: Instituto Nacional de Estadística e Informática; 2009.

7. Instituto Nacional de Desarrollo de Pueblos Andinos, Amazónicos y Afroperuanos (INDEPA). Mapa etnolingüistico del Perú. Rev Peru Med Exp Salud Publica 2010; 27(2):288-291.

8. Peru. Oficina General de Epidemiología. Análisis de la situación de salud de la población Nanti. Lima: Ministerio de Salud; 2003.

9. Axelsson P, Skold P. Indigenous population and vulnerability. Characterizing vulnerability in a Sami Context. Annales de Demographie Historique 2006; 1(1):115-132.

10. Instituto Nacional de Salud Pública (INSP). 2013. Grupo de Investigación Salud y Vulnerabilidad. [accessed 2013 Jul 2]. Available from: http://www.insp.mx/lineas-de-investigacion/salud-y-grupos-vulnerables.html

11. Takahashi RF, Oliveira MAC. A operacionalizaçào do conceito de vulnerabilidade no contexto da saúde da família. São Paulo: Ministerio da Saúde; 2001.

12. Peru. Congreso de la República. Ley para la protección de los pueblos indígenas $u$ originarios en situación de aislamiento y en situación de contacto inicial, situación de las reservas indígenas. Lima: Congreso de la República; 2006.

13. Peru. Instituto Nacional de Salud. Normas y guías técnicas en salud, Indígenas en Aislamiento y en Contacto Inicial. Lima: Instituto Nacional de Salud; 2008.

14. Peru. Defensoría del Pueblo. Pueblos indígenas en situación de aislamiento y contacto inicial. Informe defensorial $N^{\circ}$ 101. Lima: Defensoría del Pueblo; 2006.

15. Brackelaire V. Situación de los últimos pueblos indígenas aislados en América latina (Bolivia, Brasil, Colombia, Ecuador, Paraguay, Perú, Venezuela). Diagnóstico regional para facilitar estrategias de protección. Reporte final. Brasilia: Fundación Nacional del Indio, Centro de trabajo indigenista; 2006.

16. Finer M, Jenkins CN, Pimm SL, Keane B, Ross C. Oil and gas projects in the Western Amazon: threats to wilderness, biodiversity, and indigenous peoples. PLoS One 2008; 3(8):e2932.

17. Misioneros Dominicos. Misión El Rosario - Sepahua. Lima: Centro Cultural José Pío Aza; 2010. [accessed 2013 Aug 10]. Available from: http://www.selvasperu. org/gruposetnicos/m_7.html.

18. Hern WM. The impact of cultural change and population growth on the Shipibo of the Peruvian Amazon. The Latin American Anthropology Review 1992; 4(1):38.
19. La Ruche G, Tarantola A, Barboza P, Vaillant L, Guequen J, Gastellu-Etchegorry M; epidemic intelligence team at InVS. The 2009 pandemic H1N1 influenza and indigenous population of the Americas and the Pacific. Euro Surveill 2009; 14(42):pii=19366.

20. Culqui DR, Trujillo OV, Cueva N, Aylas R, Salaverry $\mathrm{O}$, Bonilla C. Tuberculosis en la población indígena del Perú 2008. Rev Peru Med Exp Salud Publica 2010; 27(1):8-15.

21. Zavaleta C, Fernandez C, Konda K, Valderrama Y, Vermund SH, Gotuzzo E. High prevalence of HIV and syphilis in a remote native community of the Peruvian Amazon. Am J Trop Med Hyg 2007; 76(4):703-705.

22. Ormaeche M, Whittembury A, Pun M, Suárez-Ognio L. Hepatitis B virus, syphilis, and HIV seroprevalence in pregnant women and their male partners from six indigenous population of the Peruvian Amazon Basin, 2007-2008. Int J Infect Dis 2012; 16(10):e724-730.

23. Jokisch BD, McSweeney K. Assessing the potential of indigenous-run demographic/health surveys: the 2005 Shuar survey, Ecuador. Hum Ecol 2011; 39(5):683-698.

24. Pereira NOM, Santos RV, Welch JR, Souza LG, Coimbra CEA. Demography, Territory and Identity of Indigenous Peoples in Brazil: The Xavante Indians and the 2000 Braziliam National Census. Hum Organ 2009; 68(2):166-180.

25. Gurven M. Infant and fetal mortality among a high fertility and mortality population in the Bolivian Amazon. Soc Sci Med 2012; 75(12):2493-2502.

26. De Souza LG, Santos RV, Coimbra CEA. Estrutura etária, natalidade e mortalidade do povo indígena Xavante de Mato Grosso, Amazônia, Brasil. Cien Saude Colet 2010; 15(Supl. 1):1465-1473.

27. United Nations (UN). Principles and recomendations for populations and housing censures, revision 2. New York: UN; 2007.

28. Luo ZC, Kierans WJ, Wilkins R, Liston RM, Uh SH, Kramer MS. Infant mortality among First Nations versus non-First Nations in British Columbia: temporal trends in rural versus urban areas, 1981-2000. Int J Epidemiol 2004; 33(6):1252-1259.

29. Hern WH. Health and demography of native Amazonians: historical perspective and current status. Cad Saude Publica 1991; 7(4):451-480.

30. World Health Organization (WHO), Global Health Observatory Data Repository. Mortality and burden of disease child mortality. Geneva: WHO; 2013.

31. Casas JA, Dachs JN, Bambas A. Health disparities in Latin America and the Caribbean: The role of social and economic determinants. Washington: Pan American Health Organization; 2001.

32. Garnelo L, Brandao LC, Levino A. Dimensions and potentialities of the geographic information system on indigenous health. Rev Saude Publica 2005; 39(4):634640 .

33. Hinrichsen D. Working from within and from without - Jambi Huasi - a model for community empowerment. New York: UNFPA; 2006.

34. Larrea C, Montenegro Torres F. Ecuador. In: Hall G, Patrinos HA, editors. Indigenous Peoples, Poverty and Human Development in Latin America. New York: Palgrave Macmillan; 2006. p. 67-105. 
35. Larrick J, Yost J, Kaplan J, King G, Mayhall J. Patterns of health and disease among the Waorani Indians of Eastern Ecuador. Medical Anthropology 1979; 3(2):147-189.

36. Pringle $H$. Indigenous people. Uncontacted tribe in Brazil emerges from isolation. Science 2014; 345(6193):125-126.

37. Early JD, Peters JF. The population dynamic of the Mucajai Yanomama. New York: Academic Press; 1990.

38. Gross DR. Tropical forest hunters and the economy of sex in peoples and cultures of native South America: an anthropological reader. New York: The Natural History Press; 1973.

39. Price D. Notes on Nambiquara demography. South Am Indian Stud 1994; (4):63-76.

40. Souza LG, Santos RV. Demographic profile of the Xavante Indian population in Sangradouro-Volta Grande, Mato Grosso. Cad Saude Publica 2001; 17(2):355-365.

41. Cabezas C. Pruebas rápidas para el diagnóstico de la malaria: una necesidad en áreas rurales con limitado acceso al diagnóstico microscópico. Rev Peru Med Exp Salud Publica 2006; 23(2):79-80.

42. La República. Indígenas Nahua comunican al gobierno que impedirán expansión del Lote 88. La República, 6-8-2013. [accessed 2013 Aug 10] Available from: http://www.larepublica.pe/06-08-2013/indigenas-nahua-comunican-al-gobierno-que-impediran-expansion-del-lote- 88

43. Peru. Defensoría del Pueblo. Oficio $N^{\circ} 1132-2013-D P$. Lima: Defensoría del Pueblo; 2013. [accessed 2013 Aug 10]. Available from: http://puma.defensoria.gob. pe/modules/Downloads/documentos/Oficio-N-11322013-DP.pdf

44. Belizán JM, Cafferata ML, Belizán M, Tomasso G, Chalmers B. Goals in maternal and perinatal care in Latin America and the Caribbean. Birth 2005; 32(3):210-218.

Artigo apresentado em 13/04/2014

Aprovado em 19/05/2015

Versão final apresentada em 21/05/2015 